\title{
PENGALAMAN BERMAIN VIDEO GAMES SEBAGAI KEGIATAN LEISURE CLASS MIDDLE LOWER REMAJA KAMPUNG TANOKER
}

\author{
Juariyah \\ Prodi Ilmu Komunikasi Fakultas Ilmu Sosial dan Ilmu Politik \\ Universitas Muhammadiyah Jember \\ Juariyah@unmuhjember.ac.id
}

\begin{abstract}
Playing inherent in human life ranging from children, adults, and parents, feel the play is fun, thus. playing older than culture. Man's human instinct has been around since infancy to toddlers, teenagers, and so on, all of which are part of human instinct. This is because games or games provide usability of hone skills such as thinking, making strategies, and simultaneously for fun. This study was conducted to explore more information about the culture of playing video games in the perspective of the Leisure Class Middle Lower in Jember District. There are eight informants who will be the source of data coming from militant gamers. The theory used is LeisureClassThorsnton Veblen. The results of some gamers feel that playing video games initially just fill the spare time there is also only invited friends, but eventually become addicted. And the habit of playing this video game was initially introduced by friends of elementary school age, usually on holidays or school. As adults they can not escape from the habit of playing video games and play them through the games on the phone. Seeing this fact shows playing video games become part of his day to day activities, and to fill his spare time.
\end{abstract}

Keywords: Playing Culture, video games, Leisure Class

\begin{abstract}
ABSTRAK
Bermain melekat dalam kehidupan manusia mulai dari anak-anak, dewasa, dan orang tua, merasakan bermain adalah hal yang menyenangkan, dengan demikian. bermain lebih tua dari budaya. Naluri bermain manusia sudah ada semenjak bayi sampai beranjak balita, remaja, dan seterusnya, kesemuanya merupakan bagian dari naluriah manusia. Hal tersebut disebabkan game atau permainan memberikan kegunaan yaitu mengasah kemampuan seperti berpikir, membuat strategi, dan sekaligus untuk kesenangan. Penelitian ini dilakukan untuk menggali lebih banyak informasi tentang budaya bermain video game dalam perspektif Leisure Class Middle Lower di Kabupaten Jember. Terdapat 8 informan yang akan menjadi sumber data yang berasal dari gamer militan. Teori yang digunakan adalah Leisure Class Thorsnton Veblen. Hasil penelitian sebagian gamer merasakan bahwa bermain video game awalnya hanya mengisi waktu luang saja ada pula hanya diajak teman, tetapi lama-kelamaan menjadi kecanduan. Dan kebiasaan bermain video game ini pada awalnya banyak diperkenalkan oleh teman waktu usia sekolah dasar, biasanya pada hari libur atau pulang sekolah. Beranjak dewasa mereka tidak bisa lepas dari kebiasaan bermain video game dan memainkannya melalui game yang ada di handphone. Melihat kenyataan ini menunjukkan bermain video game menjadi bagian dari kegiatannya sehari hari, dan mengisi waktu luangnya.
\end{abstract}

Kata-kata kunci: Budaya Bermain, video game, Leisure Class 


\section{PENDAHULUAN}

Perkembangan permainan video game yang kita kenal sekarang berawal dari seorang etnografer yang bernama Steward Culin menciptakan karyanya yang berjudul Games of the North American Italian yang dipublikasikan pada tahun 1907 dan Harold James Ruthven Murray karyanya berjudul History of Chess pada tahun 1913. Kedua karya tersebut sampai sekarang menarik dipelajari. Perlu kita ketahui bahwa games sangat berhubungan dengan simulasi (tiruan dari operasi sistem yang luas oleh sistem lain yang disederhanakan). Simulasi yang bertujuan pembelajaran dengan bermain bisa disebut bentuk tertua dari metode pembelajaran bahkan binatangpun belajar dengan menirukan seperti bentuk simulasi bersembunyi atau berkelahi. Tahun 1950 an kelompok gamer Amerika terbentuk dengan nama The East Coast War Games Council, sebuah organisasi yang mengatur serangkaian simposium dan menerbitkan prosiding dan pertemuan. Tahun 1960-an nama kelompok tersebut berubah menjadi The North American Simulation and Gaming (NASAGA).

Pada tahun 1970 terbentuklah organisasi internasional yang disebut International Simulation and Games Association (ISAGA). Organisasi ini telah mengadakan konferensi yang melibatkan peneliti yang fokus pada games dan simulasi dan kegunaannya untuk berbagai tujuan terapan. Sebuah jurnal akademik yang terbit berjudul Simulation \& Gaming jurnal ini menjadi jurnal publikasi reguler yang tertua. Tahun 1987 mengubah namanya menjadi The Association for the Study of Play (TASP). Asosiasi ini menjadi tempat penting bagi pengembangan dan menerbitkan penelitian permainan : Play and Culture (1988-1992), Journal of Play Theory and Research ( 1993-1997) dan Play and Culture Studies (1998sekarang).

Penelitian ini berawal dari penulis melihat fenomena yang pertama, banyaknya anak-anak beralih memilih permainan tradisional ke permainan modern (game modern), mulai anak-anak, remaja, dari bangku sekolah dasar, menengah pertama sampai mahasiswa, betah duduk berjam-jam bermain game online baik pagi, sore, maupun malam hari, keadaan ini ditemukan baik di lingkungan perkotaan maupun pedesaan. Hanya caranya yang berbeda, cara gamer menghabiskan waktu bermain dalam konteks kehidupan desa sangat berbeda dengan kehidupan di manapun sebagai contoh, dalam lingkungan masyarakat desa, ketika kita melihat rumah sewa 
game, seringkali kita melihat satu anak yang bermain sedangkan yang lain ikut sebagai penonton, mereka saling menikmati kebersamaan dalam bermain video game. Begitu pula yang terjadi di Kabupaten Jember, Fenomena ini sangat berbeda jika di kota misalnya, masingmasing anak tenggelam dalam dunianya sendiri tidak bersama-sama menikmati permainan dengan teman di sekitarnya.

Fenomena yang kedua adalah munculnya usaha warnet di desa-desa, bagi masyarakat desa, membuka usaha warnet dirasakan paling mudah dan murah dengan bermodalkan uang 10 juta mereka sudah bisa membuka usaha warnet, begitu pula yang terjadi di Kabupaten Jember, meskipun banyak daerah yang menggunakan layanan titik hotspot jaringan internet, tetapi usaha warnet tetap menjadi primadona, hal ini ditandai dengan jumlah pengunjung warnet yang setiap hari tetap ramai (kabarbisnis.com, 8 Februari 2009).

Studi yang dilakukan tentang permainan videogame yang berada di lingkungan pedesaan tepatnya di Kecamatan Ledokombo pernah dilakukan oleh Triono Akmad Munib dkk (2011) menunjukkan Kecamatan Ledokombo daerah yang banyak terdapat industri warnet yang menyajikan permainan modern (video game), hal ini ditandai adanya warnet SS Net, Rumah warnet kediaman Bapak Herman, Bapak Mulyono, dan Ibu Ginten. Kegiatan libur anak-anak banyak yang dihabiskan di rumah PS tersebut. Mereka banyak yang keluar rumah izinnya mengaji dan les tetapi adanya di tempat bermain video game. Hadirnya Tanoker hanya sekitar 30 persen dapat mengurangi bermain video game, angka ini masih sangat kecil, artinya anak-anak di Kecamatan Ledokombo masih banyak yang menyukai permainan video game

Peneliti ingin memaparkan kondisi secara sosial dan budaya dalam kajian Leisure Class Theory. Leisure merupakan aktivitas-aktivitas, teman-teman, dan sarana-sarana yang berkaitan dengan kegiatan tersebut yang dipilih secara bebas untuk mencapai kepuasan atau kesenangan pribadi. Pada umumnya aktivitas ini adalah suatu aktivitas yang dibutuhkan manusia (Innurtrisniyati, 2008). Teori ini menjelaskan tentang perilaku seseorang dalam menggunakan waktu luangnya. Dalam perkem-bangannya pengertian leisure diartikan sebagai kelas "pemboros", yang mengeluarkan banyak cost demi mengaktualisasikan keinginan atau hasrat dalam penggunaan waktunya. Oleh karenanya, kelompok yang disebut 
sebagai Leisure Class menjadikan gaya hidup mereka sebagai bagian identitas diri.

Studi ini berusaha memahami bermain dengan dua konsep yang berbeda, yaitu bermain (play) sebagai budaya universal karena bermain penting bagi sifat manusia, dan bermain sebagai aktivitas yang menyenangkan yang mengacu pada gerakan yang dibuat seseorang saat memainkan permainan (game). Dua hal yang berbeda, yang ingin diteliti yaitu bermain video game (permainan) dengan perangkat permainan modern dengan bermain (play) dengan perangkat permainan tradisional dan pendekatan budaya bersama komunitas Tanoker Ledokombo, dalam lingkungan masyarakat middle lower. Sebagai aktivitas dalam mengisi waktu luangnya.

Teori Waktu Luang / Kenyamanan dari Veblen / The Leisure Class Theory

Leisure, atau waktu luang merupakan aktivitas-aktivitas, temanteman dan sarana-sarana yang berkaitan dengan kegiatan tersebut yang dipilih secara bebas untuk mencapai kepuasan atau kesenangan pribadi. Pada umumnya aktivitas ini adalah suatu aktivitas yang dibutuhkan oleh manusia. Vablen ( Ritzer, 2012) kritis terhadap kelas yang memiliki waktu luang, karena perannya dalam kebiasaan konsumsi secara boros.

Kata waktu luang ( leisure) berasal dari bahasa latin licere yang berarti diijinkan. Dari licere berubah menjadi kata bahasa Perancis loisir, yang berarti waktu senggang/bebas, dan bahasa Inggris license, yang berarti ijin. Jadi secara literal, waktu luang (leisure) berarti kebebasan bertindak.

Keberagaman arti dari waktu luang yang secara umum dikenal (Kraus, 1971), menyatakan kata leisure ini memiliki empat arti, (1) terkait dengan pandangan klasik, (2) konsep waktu luang sebagai suatu fungsi dari kelas sosial (3) konsep waktu luang sebagai suatu bentuk aktivitas dan (4) konsep waktu luang sebagai waktu senggang ( Kando, 1975: 21). Pendapat lain dikemukakan Larrabee dan Mayersohn (1958) waktu luang dapat berarti (1) kebebasan kesempatan untuk melakukan sesuatu (2) kesempatan yang diberikan oleh kebebasan memilih tempat tinggal, (3) memiliki waktu untuk sendiri (4) musyawarah ( Kando, 1975: 22). Berger (1962) melihat dua definisi dengan tradisinya masing-masing. Satu tradisi memahami waktu luang sebagai aktu senggang, atau waktu yang tidak diperuntukkan untuk melakukan pekerjaan. Tradisi klasik yang lebih tua 
lainnya memandang waktu luang sebagai pengembangan diri dan keasyikan dengan nilai-nilai hidup yang lebih tinggi, masingmasing dengan tradisinya yaitu menganggap waktu luang sebagai waktu yang tidak dikhususkan untuk pekerjaan berbayar, dan kenyamanan yaitu kultivasi diri dan keasyikan dengan nilai kehidupan yang lebih tinggi. Smigel (1963) mengenal dua definisi dari waktu luang. Satu memandang waktu luang sebagai kebebasan dari kebutuhan menjadi "sibuk" yang lain menyamakan waktu luang dengan waktu senggang. Smigel dan Berger contohnya secara esensi mengau pada pembagian yang sama, Berger berbicara dari tradisi klasik yang memandang waktu luang sebagai pemuliaan diri, meditasi, seperti dalam teori Aristoteles, Smigel mencatat bahwa satu konsep dari waktu luang adalah merupakan semacam "kebebasan”. Secara esensi, kedua penulis mengacu pada suatu konsep klasik dan normatif tentang waktu luang seperti yang telah disampaikan para filsuf, tokoh budaya, pembaru, singkatnya oleh mereka yang memandang waktu luang sebagai sesuatu yang ideal. Konsep alternatif yang dikenal oleh kedua penulis ini sama yaitu waktu luang. Pembedaan waktu luang, ada penggunaan istilah secara normatif atau klasik dan ada penggunaan deskritif, empiris. Penggunaan yang kedua menghindari masalah-masalah filosofi dan hanya berkisar pada apa yang orang lakukan dalam waktu senggang mereka. Penggunaan empiris kata waktu luang ini lebih bisa dipahami oleh banyak orang. ( Kendo, 1975:21).

\section{Bermain sebagai Budaya}

Kata bermain (play) berasal dari bahasa Latin plaga, yang berarti pukulan atau dorongan, seperti saat memukul instrumen atau memukul bola. Bahasabahasa Indo-Jerman lainnya memakai kata-kata yang berhubungan dengan bermain. Bahasa Jerman spielen dan bahasa Belanda spelen, contohnya, secara etimologi dan semantik dekat dengan bermain (play) dalam bahasa Inggris. Kata-kata tersebut tidak hanya berasal dari rumpun yang sama tetapi juga mengandung arti yang kurang lebih sama, contohnya, bermain olah raga, alat musik, dan pemainan. Tentu saja terjadi pergeseran; contohnya, ketika teater kita bermain/tampil tidak diartikan secara literal sebagai Spiel atau spel dalam bahasa-bahasa German ini, kata-kata tersebut, dilain pihak, mencakup arti dari kata permainan (game). Jadi dalam bahasa Inggris, bermain harus dibedakan dari 
permainan (game), suatu perbedaan yang akan dibahas sebentar lagi.

Ketika kita membahas terminologi bermain, dalam buku Homoludens (Huizinga, 1938: 27) bermain merupakan kegiatan sukarela dan manusia adalah makhluk yang senang akan bermain. Huizinga mengidentifikasikan tentang bermain menjadi lima yakni bahwa (1) bermain itu bebas atau berhubungan dengan kebebasan, (2) bermain bukanlah kehidupan yang sesungguhnya, (3) bermain membedakan dari kehidupan sesungguhnya baik tempat dan durasi, (4) bermain menciptakan aturan dan bermain membutuhkan aturan yang tertinggi dan absolut, (5) bermain tidak berhubungan dengan kepentingan yang bersifat material dan tidak ada keuntungan profit dari bermain. Konsep kata bermain tidak mudah untuk menjabarkan, seperti yang dikemukakan oleh Piaget (1951) bermain merupakan kegiatan yang dilakukan berulang-ulang, demi kesenangan seseorang melakukan kegiatan berulangulang karena menyenangkan. Demikian pula yang dikemukakan oleh Hughes (1999) dalam bukunya Children, play, and Development, mengemukakan, bermain merupakan hal yang berbeda dengan belajar dan bekerja. Suatu kegiatan yang disebut bermain meliputi lima unsur yaitu:
(1) mempunyai tujuan yaitu permainan itu sendiri untuk mendapatkan kepuasan, (2) memilih dengan bebas dan atas kehendak sendiri, tidak ada yang menyuruh ataupun memaksa, (3) menyenangkan dan dapat menikmati, (4) mengkhayal untuk mengembangkan daya imaginatif dan kreativitas, dan (5) melakukan secara aktif dan sadar (Hughes, 1999). Dalam psikologi perkembangan, perkembangan sosial ditandai dengan kemampuan berinteraksi. Bermain pada masa anakanak memiliki karakteristik yang membedakannya dari permainan orang dewasa.

\section{Games dalam Konteks Masyarakat Indonesia}

Perkembangan bisnis warnet (warung internet) di Indonesia selalu ramai, mayoritas orang yang datang ke warnet lebih banyak yang bermain game terutama game online, tren permainan game ini mulai dikenal pada mulanya dengan yang kita sebut nintendo atau playstation yang tidak mengharuskan terkoneksi dengan internet. Tahun 2000an game online mulai masuk ke industri game. Game online membutuhkan gadget atau PC (Personal Computer) yang harus terkoneksi dengan internet. 
Di Indonesia animo masyarakat terhadap game begitu besar, terutama game online penggunanya lebih dari 15 juta user dan kurang lebih ada 3000 perusahaan pengembang dan 20 publisher game online di Indonesia. Sekilas tentang game online pada mulanya dikenal dengan Massively Multiplayer Online Game (MMOG). Multiplayer dalam konteks game dimainkan lebih dari satu orang, sedangkan game online permainan berbentuk video dan melibatkan koneksi internet, jadi pengertian massively multiplayer online game $(\mathrm{mmog})$ adalah sistem permainannya seperti video games yang tidak membutuhkan koneksi internet, tetapi karena adanya koneksi internet menyebabkan banyak pemain dalam game tersebut, pemainnya bisa berasal dari negara kita atau negara lain. Untuk memainkannya setiap pemain harus menginstal software dari game tersebut.

Perkembangan $M M O G$ pada mulanya pada tahun 2001 yaitu munculnya Xbox oleh Microsoft, selanjutnya Sonny mengembangkan PSP atau Playstation Portable. Pada tahun 2004 muncul world of warcraft. Subscribers yang mengakses mencapai 10 juta subcribers. Jumlah yang fantastis, selanjutnya $M M O G$ kini menawarkan lets get rich yaitu program di mana ketika kita memainkan game dapat terkoneksi dengan seluruh dunia dan memainnkannya dalam waktu yang bersamaan. Bila kita kaji dari sisi bisnis, perkembangan game di Indonesia sangat pesat dan menghasilkan peluang bisnis baru dengan penjualan game-game online yang baru.

Menurut survei Asosiasi Penyelenggara Jasa Internet Indonesia (APJII) jumlah pemain game online di Indonesia mencapai lima belas (15) juta orang, enam juta diantaranya adalah pemain yang militan, artinya orang yang setiap hari bermain game online. Militansi bermain game online ini disebabkan oleh identifikasi antara diri aktual dan avatar maya (Suryajaya, 2014).

\section{METODE}

Penelitian ini menggunakan metode etnografi. Pendekatan penelitian etnografi digunakan untuk menggambarkan, menginterpretasikan dan memahami karakteristik setting sosial dengan gejala beragam budaya dan berbagai interpretatifnya atau ekspresinya dan mengadopsi pendekatan emik, artinya peneliti menginterpretasikan data dari perspektif orang - orang dalam settingcultureyang diteliti (Flick Uwe etc 2004:224). Penggunaan metode etnografi ini karena tema dan setting penelitian 
cocok dengan karakteristik etnografi yaitu (1) aktivitas bermain yang dilakukan anakanak dalam game modern secara psikologis melalui pengamatan, akan menggambarkan konsep bermain yang berbeda, pentingnya bermain dalam tahap kehidupan bahkan menjadi kebutuhan, bermain juga digambarkan sebagai keluarnya energi yang penting secara berlebihan, untuk mencapai kepuasan atau sebagai kebutuhan untuk relaksasi (Huizinga, 1938:2). Hal tersebut terkait dengan fenomena sosial budaya masyarakat, (2) peneliti melakukan pengamatan dan pengumpulan data yang tidak terstruktur yang menggambarkan masyarakat dengan kehidupan budayanya memberi makna pada game, dan (3) analisis data berdasarkan interpretasi eksplisit dari sebuah makna dan fungsifungsi tindakan yang berdasarkan pendekatan emik, selanjutnya hasil dari proses tersebut adalah berupa deskripsi suatu fenomena sosial.

Metode pengumpulan data dalam penelitian ini meliputi teknik wawancara mendalam, dan observasi partisipan. Wawancara mendalam (depth interview), adalah serangkaian pertanyaan terbuka yang digunakan untuk memperoleh informasi rinci atau deskriptif dari individu tentang topik penelitian (Kalof, Dan
Thomas Diez, 2008 :120). Peneliti dalam penelitian ini mengambil bagian dari situasi dan merasakan bagaimana perasaan orang-orang dalam situasi tersebut, artinya menyatu pada realitas orang-orang secara sungguh-sungguh dan menyatu secara total. Secara operasional, wawancara mendalam bersifat luwes, susunan pertanyaan dapat diubah pada saat wawancara, disesuaikan dengan kebutuhan dan kondisi saat wawancara, yang memungkinkan pihak yang diwawancara untuk mendefinisikan dirinya sendiri dan pengalamannya serta menggunakan istilah-istilah mereka sendiri sesuai dengan fenomena yang diteliti. Untuk itu, dalam wawancara mendalam selalu diupayakan agar subjek penelitian tidak hanya menjawab secara jujur tetapi juga cukup lengkap, terjabarkan dan didorong untuk mengemukakan semua perasaannya dengan bebas dan nyaman. Kelompok yang menjadi objek analisis penelitian ini adalah penikmat game yang meliputi gamer militan sebanyak 7 orang.

Teknik kedua yang digunakan peneliti dalam penelitian ini adalah observasi partisipan. Observasi partisipan dimana peneliti membenamkan diri dalam penelitian, berkenaan dengan orang-orang yang mereka amati, dan aktif (peserta) 
dalam pengaturan (Kalof, Dan Thomas Diaz , 2008 :115). Fokus observasi yang dimaksud antara lain pengamatan untuk memperkaya informasi dalam pengumpulan keterangan kajian ini, melihat aktivitas gamer dan aktifitas komunitas Tanoker. Adapun teknik penarikan data atau sumber data menggunakan snowball. Untuk jumlah informan, sejak awal studi ini tidak membatasi jumlah informan yang diwawancarai, karena yang lebih penting adalah seberapa jauh data yang diperoleh telah "jenuh" dan tidak ditemukan lagi halhal baru di lapangan.

Dalam penelitian ini, proses analisis data dilakukan mulai sejak awal proses pengumpulan data di lapangan yaitu dengan melakukan proses klarifikasi data yang diperoleh dari dokumentasi dengan hasil observasi dan wawancara awal di lapangan. Setiap hasil analisis dikaitkan dan dikembangkan kembali dengan subjek kajian dengan melalui proses pengumpulan data lanjutan dengan informan penelitian. Untuk menjawab fokus penelitian, maka seluruh data yang diperoleh, seperti data dari hasil wawancara dan data hasil observasi, disusun dalam bentuk transkrip. Setelah transkrip selesai, kemudian dipilah-pilah atas dasar tema dengan mencari kata-kata kunci sebagaimana yang diungkapkan oleh informan penelitian untuk membangun konsep-konsep yang relevan dengan tema penelitian. Setelah tahap tersebut selesai maka dilakukan kategorisasi berdasarkan konsep-konsep penelitian.

Langkah berikutnya adalah membuat deskripsi tentang isu penelitian yang dan dianalisis serta diinterpretasikan sesuai dengan fokus penelitian. Kemudian peneliti mencoba untuk menyusun proposisi atas dasar temuan/data dan membandingkan antara temuan dan teori, hasil-hasil terdahulu atau informasi dari para ahli.

Untuk memperoleh data tentang dinamika sebuah kampung dengan keberadaannya dan menjadi sebuah tempat industri game, sesuai dengan perspektif penelitian yang digagas dalam penelitian ini, yaitu penelitian kualitatif, dan pendekatan etnografi yang digunakan, maka teknik analisis yang digunakan dalam penelitian ini adalah teknik analisis kualitatif.

\section{PEMBAHASAN}

Video game merupakan permainan yang sangat digemari pada saat ini. Seperti yang disampaikan (Suryajaya, 2014), Video game, adalah bentuk termaju dari budaya pop masa kini. Berbeda dengan 
film, musik dan komik, video game merupakan bentuk budaya pop kontemporer yang paling mampu memroduksi dan mereproduksi budaya dan ideologi dalam benak para penikmatnya. Pendekatan kajian games komputer menggunakan metode yang disusun dalam kajian budaya yang digunakan untuk mempelajari budaya populer. Dalam kebiasaan/tradisi ini, dikatakan secara umum bahwa budaya populer dipahami sebagai sisi penting baik sirkulasi/aliran maupun pemban-tahannya atas idiologi dominan. Studi Budaya menunjukkan kepada kami cara-cara berpikir tentang konsumsi media, identitas dan kesenangan dalam kehidupan seharihari. Pendekatan yang luas ini akan menemukan fokus melalui tradisi-tradisi yang muncul dari Studi Media Baru. Yaitu Studi media yang mengambil media digital sebagai obyek penelitiannya, tetapi juga merupakan hal baru dalam pengertian bahwa proses ini mempunyai efek mengkonfigurasi ulang tradisi kajian media itu sendiri

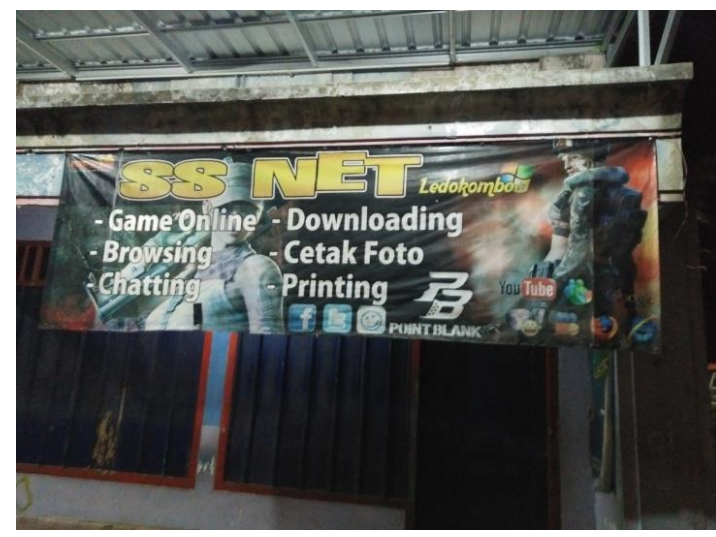

Gambar 1. Tempat bermain Video Game SS Net Kediaman Bapak Antok

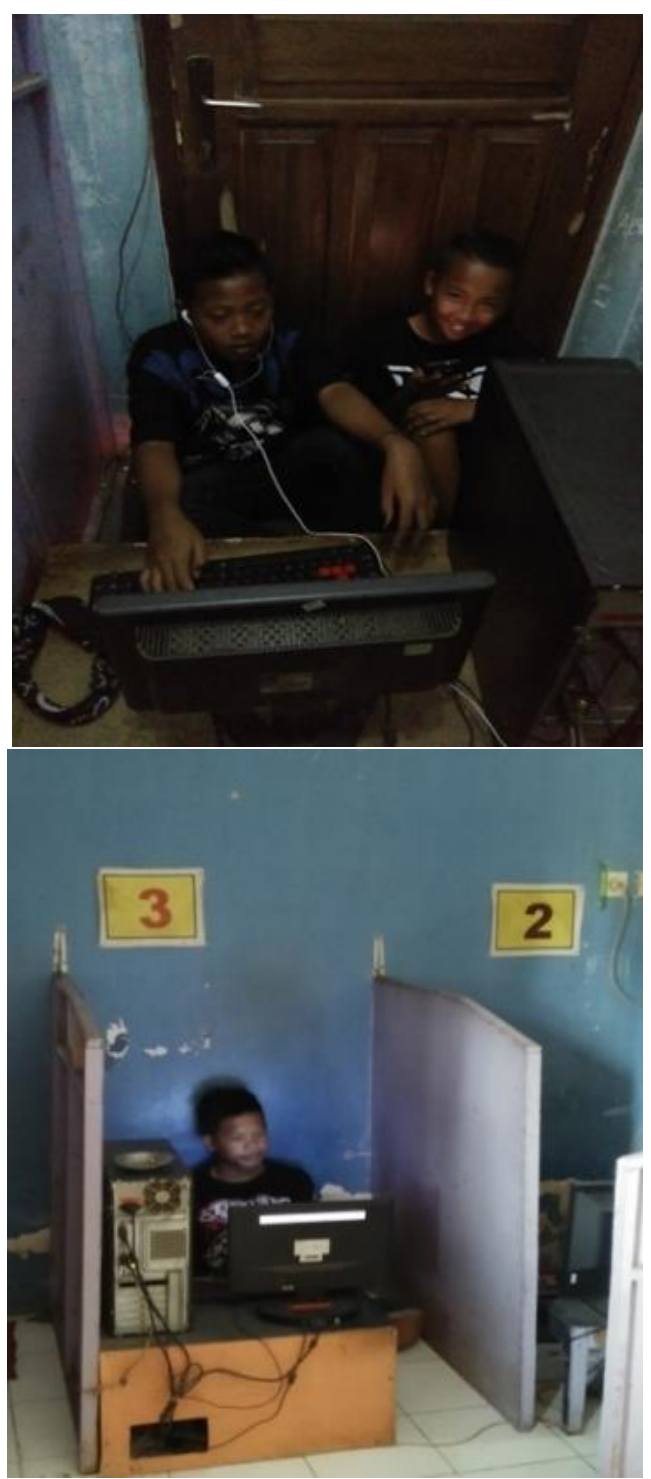

Gambar 2. Anak-anak bermain di Video Game Pedesaan 
Kondisi inilah tempat bermain video game yang ada di Desa Ledokombo tempatnya sangat lembab dan duduk di bawah, mereka menikmati rumah rental game online kediaman Bapak Antok yang buka sejak pagi hari sampai malam terutama di hari libur mulai pagi pagi sudah ramai. Tempat rental ini hanya dibatasi oleh sekat-sekat saja, dan tempatnya sempit. Tempat ini melayani selain bermain video game online, juga bisa browsing, chatting, printing, cetak foto, dan downloading. Budaya bermain video game di Indonesia menjadi permainan yang paling digemari. Tetapi kondisi ini sarat dengan budaya lokal di desa seperti pada saat hari jumat, tempat ini tutup karena mereka melaksanakan sholat jumat, begitu juga pada saat-saat waktu sholat seperti dhuhur, asyar dan magrib. Kalau isya waktunya lumayan panjang.

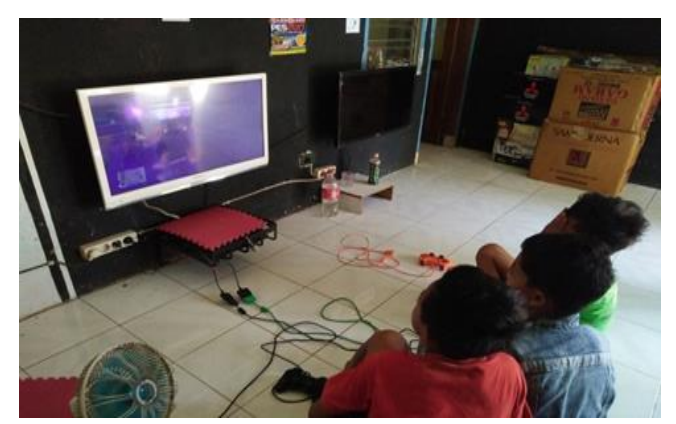

Gambar 3. Bertiga bermain bersama PS 3

Bermain adalah aktivitas yang menyenangkan bisa bermain bersama itu hal yang membahagiakan bagi anak-anak karena dunia mereka sebagian besar digunakan bermain. Inilah bedanya bermain di lingkungan desa dan bermain di lingkungan kota. Satu perangkat digunakan bertiga sedangkan stik yang tersedia hanya untuk dua orang, jadi ada satu orang yang menjadi penonton, bagi mereka asyik-asyik saja menikmati permainannya. Toh sewa rentalnya juga dibagi bertiga jadi biayanya ringan inilah lingkungan desa dengan dana sedikit bisa menikmati bersama.

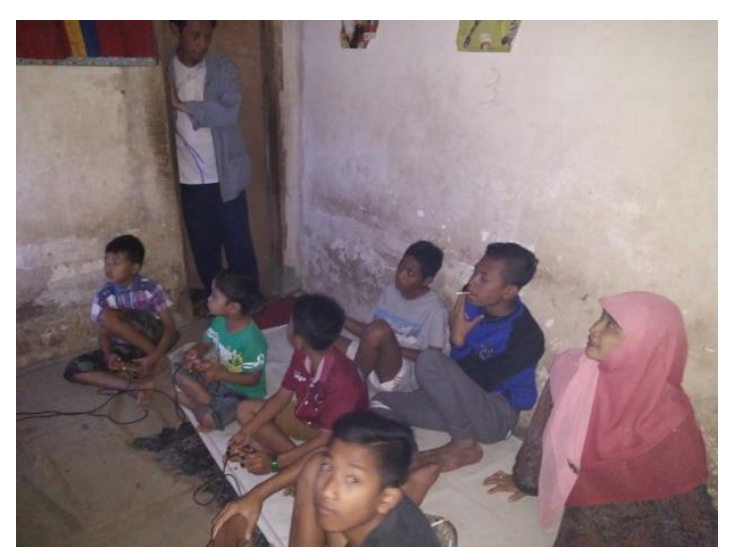

Gambar 4. Beramai-ramai menikmati permainan video game

Rumah rental kediaman Bapak Mulyono ini buka setiap hari, yang datang untuk bermain tidak hanya anak-anak sepulang dari sekolah atau di waktu hari libur, tetapi juga bagi dewasa dan siapa saja yang berminat bermain video game di rumah Bapak Mulyono ini. Playstation 2 yang ada di rumah Bapak Mulyono ini sudah berbasis harddisck, jadi hanya menginstal saja berlangganan ke Jember 
kota jika ingin menginstal perangkatnya.

Berbeda dengan yang menggunakan kaset, lebih boros dan cepat bosan. Kalau diperhatikan di rumah Bapak Mulyono ini yang menggunakan unit ada dua tetapi yang memegang stik ada empat orang dua orang lagi hanya menonton saja.

Konteks bermain video game di Ledokombo pada umumnya menjadi tempat kumpulnya anak-anak di dalam menggunakan waktu luangnya. Mereka bersama-sama sebagai pemain dan penonton. Hari libur merupakan hari yang paling ramai di tempat rental ini. Bermain video game menjadi budaya baru bagi anak-anak di Indonesia mereka bermain bersama-sama satu perangkat dimainkan beramai-ramai. Semakin banyak anakanak semakin asyik dan lupa waktu.

Pendapat informan bermain video game dalam penelitian ini adalah sebagai berikut (Fatoni Akbar, 23 tahun):

"Pengalaman saya mengenal video game pada saat usia SD, waktu itu dikenal dengan $P S-1$, berada di tempat warnet adalah hal yang menyenangkan, saking asyiknya bermain sampai-sampai pernah pada waktu SMA kena razia Satpol $\mathrm{PP}$, pengalaman itu masih terus membekas sampai sekarang, uang yang digunakan untuk bermain game biasanya dari uang jajan, seiring berjalannya waktu saya lebih senang game yang mengandung kekerasan seperti smackdown, atau jotos-jotosan. Jenis game/permainan lain adalah smackfore, berpetualang dan marketing. Adapun untuk mengeksplor game tidak ada keinginan dan tentang adiktif /kecanduan belum sampai kearah itu karena bermain game ini hanya diajak teman saja"

Jadi, bagi Fatoni pengalaman bermain game lebih karena pengaruh teman. Game yang mengandung kekerasan lebih disukai. Menurut peneliti game Eugene Provenzo (2012) , mengemukakan bahwa target utama pengguna video game adalah anakanak dan games telah dikembangkan dengan kekerasan, seks, dan konten rasis dalam jumlah yang besar. Pemikiran Provenzo ini berdasar pada gagasan bahwa video games mengubah pengguna dari penonton pasif menjadi partisipan yang lebih aktif melalui keterlibatannya dengan teks media. Pendapat lain yang dikemukakan pakar psikolog Dr. Phil (2011) menyatakan bahwa game kekerasan mengaktifkan pusat kemarahan mereka dan merupakan dampak yang tidak kentara. Akibat dari tren dan kepentingan anak dalam bermain game dapat dilihat dengan cara melihat sudut pandang pemain dalam pembahasan tentang problematika bermain game. Walaupun pemain game mungkin menggunakan kata "kecanduan" untuk berbicara tentang perilaku bermain 
mereka dan merujuk pada games seperti Evercrack dan World of Warcrack, ketika berbicara tentang kecanduan game secara keseluruhan, secara umum, mereka menempatkan perdebatan dengan cara memusatkan perhatian kepada problematika kegunaan game pada beberapa individu. Penelitian yang dilakukan oleh Winsen Sanditaria (2014), yang berjudul Adiksi Bermain Game Online Pada Anak Usia Sekolah hasilnya adalah bahwa $62 \%$ anak-anak yang bermain game online ini mengalami adiksi, dan sebanyak $38 \%$ tidak mengalami adiksi. Salah satu yang menyebabkan kecanduan bermain video game ini karena menariknya permainan yang disajikan dengan efek audio dan visual yang ditampilkan membuat pemain betah berada di depan komputer.

Informan lain berpendapat, adalah Rio (19 tahun) :

"Pertama kali mengenal video game adalah Playstation 1 (PS 1) waktu itu masih usia SD, biasanya mainnya kadang sendiri dan kadang bersama komunitas saat SMP pernah punya pengalaman membolos sekolah demi bermain game online, perasaannya senang berada di tempat warnet, banyak teman dan biasanya ke warnet waktu pulang sekolah, saya termasuk yang kecanduan bermain video game karena sangat menyenangkan dan bahagia sampai sekarang. Uang untuk bermain ya uang jajan kalau masih sekolah, setelah dewasa ya dari gaji ini digunakan untuk bermain video game, adapun jenisnya permainan sepak bola, GTA, setelah dewasa jenisnya berubah jadi MOBA, perang-perangan dan petualangan, kalau mengeksplor tidak pernah.”

Usia informan dalam penelitian ini adalah mereka usia kuliah artinya mereka pernah mengalami bermain permainan video game pada era game konsol dan game online, seperti Nintendo, Playstation, 1, 2, 3 dan 4. Mereka yang pada awalnya menyenangi game yang mengandung kekerasan seperti GTA, setelah dewasa biasanya menyukai jenis $M O B A$ dan perang-perangan.

Bermain video game pada awalnya hanya mengisi waktu luang, lamakelamaan menjadi kecanduan hal seperti inilah yang dirasakan banyak gamer. Salah satunya yang membuat asyik bermain video game adalah jenis MMORPG (Massively Multiplayer Online Role Player Game), menurut (Suryajaya, 2014), game ini membebaskan pemain menjadi karakter apa saja yang diinginkannya. Hasil penelitian yang dilakukan oleh Chen, K \& Ross (2010) dalam Journal of Database Management yang berjudul Antecedent of Online Game Depedency menjelaskan mengapa MMORPG ini lebih 
disukai adalah terdapat tiga (3) faktor seorang gamer mengalami ketergantungan MMOPRG ini antara lain (1) adanya partisipasi dalam komunitas virtual, (2) pengalihan dari kehidupan sehari-hari (3) adanya pengalaman estetika yang menyenangkan. Ketiga faktor tersebut membuat gamer mengalami kecanduan tidak bisa lepas dari aktivitas bermain videogame.

Pengalaman tentang mengeksplor yang disampaikan Bima Surya, 16 tahun adalah sebagai berikut:

"Bermain video game di warnet menjadi tempat yang favorit buat saya, merasa akrab dan banyak teman, pertama kali mengenal permainan ini diajak teman dan akhirnya kecanduan, seru aja kalau berada di tempat warnet ini, pengalaman yang masih terkenang pernah berbohong demi bermain game ini yaitu minta uang pada ortu bilangnya buat beli bensin, tapi uang itu digunakan untuk bermain game online, kalau jenis permainannya tidak senang dengan game yang mengandung kekerasan, senangnya jenis permainan Dota 2, tidak pernah main yang lain selain Dota 2 itu, punya komunitas, game membuat saya kecanduan, rasa penasaran ketika mengalami kekalahan inginnya main terus sampai menang."

Pengalaman yang dirasakan Bima Surya juga banyak dialami oleh banyak pemain lain, rasa penasaran itulah gejala adiktif/kecanduan. Seperti yang dikemukakan dalam American Medical Association (2012: 33), bahwa games dengan konten dewasa ditakutkan dapat membuat kecanduan. Pendapat ini dirasakan oleh kawula muda yang tenggelam dalam dunia video games menggantikan aktifitas di dunia yang sesungguhnya. Seperti sekolah, keluarga, dan teman. Situs ini mengakui bahwa kecanduan video games sebagai sebuah penyakit atau perilaku yang kacau. Selanjutnya digambarkan kecanduan video game sebagai keyakinan atau perasaan, $10-15 \%$ dari remaja yang bermain video game menderita kecanduan. Data ini harusnya menjadi perhatian bagi orang tua ketika menghadapi anak-anak yang kemungkinan menunjukkan kegembiraan terhadap video game disebabkan oleh otak yang melepas senyawa kimia yang berhubungan dengan kecanduan. Sebagian orang tua pernah melihat anaknya bersemangat sekali ketika bermain video games, berita ini bukanlah hal yang mengejutkan, sebab kekhawatiran seperti ini muncul ketika ada dugaan bahwa kecanduan terhadap video games itu nyata. Pengalaman bermain yang dialami Bima Surya seperti yang dialami informan lain mereka senang dengan game yang mengandung kekerasan. Dalam penelitian 
yang dilakukan Karen L.Becker, Olsen dan

Patricia A.Norberg yang berjudul Caution, Animated Violence Assessing the Efficacy of Violent Video Game menyebutkan bahwa permainan video game dengan jenis kekerasan sangat banyak dikonsumsi kawula muda, data yang dikumpulkan pada November 2008 yang terjual lebih dari 1,5 juta kopi (Reuters, 2008), hal ini jelas bahwa gagasan untuk mensimulasikan kekerasan di dunia nyata adalah kesuksesan komersial yang sangat besar, terutama di kalangan kawula muda. Salah satu contoh game kekerasan ini seperti Moreal Kombat dan Residenc Evil, yang secara eksplisit melakukan kekerasan kekerasan eksplisit dengan pertarungan tangan-tangan dan orang pertama sebagai komponen utama permainan. Permainan video game ini menimbulkan perilaku kekerasan, agresif dan antisosial (Anderson dan Bushman, 2001).

Pengalaman yang lain dikemukakan oleh Adit, 28 tahun, adalah sebagai berikut:

"Mengenal permainan video game ini ketika usia saya masih SD diajak teman waktu itu jenis permainannya game bola/CTR, senangnya berada di tempat warnet ini ya banyak teman sehingga menjadi tempat yang sangat favorit, lebih seru bermain dengan temanteman dibandingkan bermain sendiri, karena menjadi hobi saya akhirnya saya bekerja di warnet ini sebagai owner-nya dari hobi menjadi tempat usaha, orang tua saya tidak pernah melarang saya bermain game asal ingat waktu, pengalaman yang paling diingat adalah waktu kecil saking senengnya bermain video game pernah pamitnya pergi les tapi ternyata main game. Tidak suka game yang mengandung kekerasan, jenisnya biasanya MOBA, situs lain yang dibuka ketika bermain game biasanya situs kartun."

Penelitian yang dilakukan Kimberly

D. Thomas dengan judul Does The Endorsement of Traditional Masculinity Ideology Moderate The Relationship Between Exposure to Violent Video Games and Aggression? (2010) menyatakan bahwa saat ini video game sangat menarik dan interaktif (Gentile \& Anderson, 2003) menempatkan seorang pemain dalam perspektif orang pertama, yang harus membuat suatu keputusan untuk melakukan tindakan kekerasan sebelum melakukan tindakan yang lainnya. Permainan-permainan ini menuntut penghargaan dan perilaku antisosial (Gentile \& Anderson, 2003).

Pengalaman membuka situs lain ketika sedang bermain game sebenarnya bisa dinamakan mengeksplor, biasanya merasa bosan dan jenuh. Tapi ada juga gamer yang tidak ada keinginan yang lain kecuali game yang dia mainkan. Ada yang 
mengatakan saya setia dengan DOTA2 misalnya.

Seperti pengalaman M.Haris

Setyobudi 19 tahun adalah:

"selain bermain video game saya hobi olah raga bermain game hanya sebagai mengisi waktu luang saja, awalnya kenal video game ini waktu SD, sampai sekarang masih senang bermain permainan ini, pernah ada larangan dari orang tua karena nilainya turun waktu itu masih SMP dan sadar,kalau berbohong demi permainan ini ya, saat SMP dan SMA uang SPP digunakan untuk membeli peralatan perang-perangan misalnya pedang seperti dalam game, jenis game yang paling disuka adalah waktu kecil senang GTA, Naruto, Dragon Ball, setelah besar senangnya Dota 2 , petualangan dan strategi. Untuk pengalaman mengeksplor game biasanya game yang karakter ada tantangan-tantangannya dan kerumitan-kerumitannya."

Beberapa jenis game memiliki karakteristiknya masing-masing seperti jenis permainan sport, seperti Madden NFL (Tiburon, 2011) , memungkinkan pemain untuk bermain simulasi dari berbagai olahraga atletik. Permainan ini biasanya membutuhkan pemain yang mengelola beberapa karakter dan sering dimainkan dalam model multiplayer dengan beberapa pemain mengendalikan tim yang berbeda, mensimulasikan pengalaman balap dan memungkinkan pemain untuk mengontrol kendaraan dan berlomba dengan pemain lain untuk mencapai garis finish. Game penerbangan mensimulasikan pengalaman terbang dengan memungkinkan pemain untuk mengontrol pesawat terbang, pesawat ruang angkasa, atau mesin terbang lainnya.

Jadi dalam $R P G$, naik level adalah motivasi utamanya, beberapa RPG bahkan meminta pemain untuk terlibat yang dikenal dengan "tingkat grinding" atau level grinding yang menghabiskan banyak waktu untuk melakukan dan memerangi musuh untuk tujuan naik level. Kebanyakan pemain memandang bahwa yang membedakan RPG dengan permainan yang lain adalah $R P G$ memiliki alur cerita yang rumit yang melibatkan sejumlah besar pemain membacanya dalam bentuk dialog karakter.

Pengalaman yang dikemukakan oleh Heru Dwi ( 23 tahun), yang juga bekerja di warnet adalah sebagai berikut:

"Dari mulai pertama mengenal video game saya suka jenis permainan yang mengandung kekerasan seperti smackdown, film perang-perangan atau game kolosal dan beranjak dewasa senangnya DOTA2, sepak bola dan tembaktembakan, mengenal game ini untuk pertama kalinya diajak teman, seterusnya main sendiri pengalamannya jika sendiri tidak seramai jika bereng dengan teman- 
teman, uang jajan biasanya yang digunakan untuk bermain video game, setelah dewasa tidak lagi minta orang tua, kalau tidak mengingat kondisi keuangangan, jika mengalami kekalahan ingin terus bermain sampai menang, untuk mengeksplor belum ada keinginan hanya fokusnya bermain saja. Mengenai hal kecanduan masih belum ada mainnya ketika diajak teman saja."

Data dari pengalaman Heru Dwi di atas, menggambarkan ketika video game diperkenalkan pada masa anak-anak sudah memainkan permainan yang mengandung kekerasan seperti smackdown, maka ketika menginjak dewasa permainan jenis ini akan selalu digemarinya, hanya berbeda namanya saja tetapi isinya tetap mengandung kekerasan. Bagi Heru Dwi merasa pada dirinya masih belum kecanduan, tetapi faktanya masih tetap bermain video game dan dia sendiri bekerja sebagai operator warnet. Penelitian Neil B. Niman (2013), menyebutkan gamer menghabiskan sebanyak 2,5 miliar jam per minggu untuk bermain game. Mengapa orang suka bermain game? Penjelasan yang paling mungkin adalah karena hal itu menyenangkan.

Pengalaman yang disampaikan Rahmat Hidayat, 20 tahun adalah sebagai berikut:

\begin{abstract}
"Bermain game dapat menghilangkan stress, sampaisampai pernah bermain nonstop selama tiga hari, pertama kalinya kenal permainan ini dikenalkan oleh teman, berada di warnet ketika ketemu teman-teman rasanya seperi saudara, saking asyiknya bersama teman-teman kelompok, demi bermain game, saya rela tidak pernah jajan uang jajan selalu dikumpulkan untuk bermain game, pengalaman bolos sering sekali sampai-sampai didatangi guru BP dari sekolah, tentang jenis permainannya Point Blanck (PB), sudah dewasa Dota 2 dan pengalaman mengeksplor game pernah membuka situs lain seperti shopping."
\end{abstract}

Bagi gamer militan, berbagai cara akan dilakukannya demi tercapai keinginannya untuk bermain game. Menurut data Asosiasi Penyelenggara Jasa Internet, jumlah pemain game online ini sekitar 15 juta pemain dan 6 juta diantaranya adalah pemain yang militan yaitu orang-orang yang setiap hari bermain game online. Militansi ini disebabkan oleh identifikasi antara yang aktual dan avatarnya (Suryajaya, 2014).

Penelitian yang dilakukan oleh Shi, W., Corriveau \& Agar J (2014) yang berjudul Dead Reckoning Usung Play Pattern in Asimple 2D Multiplayer Online Game dalam International Journal of Computer Game Technology menyebutkan, konsumen/gamer ini telah menghabiskan 
20,77 milyar dolar AS untuk bermain videogame di Amerika Serikat saja pada tahun 2012, dari data ini 36 persen nya gamer bermain di ponsel pintar mereka dan 25 persen lagi bermain di perangkat nirkabel, data ini menunjukkan 62 persen pemenang bermain game secara online. Multiplayer Online Game paling banyak disukai dan merupakan salah satu industri hiburan terbesar saat ini. Akibatnya memaksimalkan pengalaman bermain bagi gamer saat bermain Multiplayer Online Game merupakan kunci keberhasilan permainan tersebut.

\section{SIMPULAN}

Berikut adalah beberapa kesimpulan pokok studi ini adalah sebagai berikut:

Pertama, sebagian besar dari informan adalah mereka yang berusia 19 tahun ke atas, hal ini dimaksudkan pada usia sekarang ini mereka mengenal perkembangan munculnya video game sepuluh tahun ke belakang, ketika itu mereka masih berusia di bawah sepuluh tahun atau belasan tahun dan industri ini sedang booming-boomingnya di masyarakat. Munculnya rumah rental di pelosok-pelosok desa menggantikan permainan tradisional dan kebiasaan lain dan beralih ke permainan modern. Di sisi lain mereka yang berusia 19-29 tahun sekarang adalah generasi yang pertama kali mengenal munculnya permainan video game seperti Nintendo, dan Playstation 1 (PS 1). Mereka bisa merasakan dan membedakan permainan yang awal pertama kali muncul dengan perkembangan permainan yang sekarang seperti Dota2, Moba, Pokemon Go dan lain-lain.

Kedua, pada umumnya informan menjadikan tempat bermain game atau rental/warnet menjadi tempat favorit walaupun bermain video game merupakan mengisi waktu luang, mereka lebih asyik dan senang jika bermain di rumah rental/warnet bersama teman atau komunitas dibandingkan bermain sendiri. Ekspresinya lebih ramai, dan jika mengalami kekalahan maka tidak dirasakan berat karena dirasakan bersama jadi biasa saja. Diibaratkan ketika mendapatkan hadiah dan memenangkan game, bagi gamer militan lebih senang memenangkan game dibandingkan jika mendapatkan hadiah.

Ketiga, permainan video game terbagi menjadi dua, ada yang game konsol dan ada yang game online. Pemain game konsol pada umumnya terdapat di pedesaan yang masih berjenis Playstation 1,2 atau 3, yang bermain ramai-ramai ada yang 3-5 orang pemain, sedangkan yang game online biasanya lebih banyak di kota, 
yang biasanya satu perangkat dimainkan satu orang walaupun dalam penelitian ini terdapat satu rumah yang menyewakan yaitu SS Net dan keberadaan tidak ada peraturan satu perangkat satu orang bisa saja dimainkan lebih dari dua orang.

Keempat, sebagian gamer merasakan bahwa bermain video game awalnya hanya mengisi waktu luang saja ada pula hanya diajak teman, tetapi lama-kelamaan menjadi kecanduan. Dan kebiasaan bermain video game ini pada awalnya banyak diperkenalkan oleh teman waktu usia sekolah dasar, biasanya pada hari libur atau pulang sekolah. Beranjak dewasa mereka tidak bisa lepas dari kebiasaan bermain video game dan memainkannya melalui game yang ada di handphone. Melihat kenyataan ini menunjukkan bermain video game menjadi bagian dari kegiatannya sehari hari, dan mengisi waktu luangnya.

Kelima, jenis permainan video game yang paling banyak dimainkan adalah game karekter atau sering dikenal dengan role-playingmassively multiplayer online $(M M O R P G)$ yang menarik banyak khalayak dari remaja hingga orang dewasa yang memungkinkan interaksi online dengan pemain lain.MMORPG menggambarkan seorang pemain bisa mengenakan identitas baru seperti baju baru, menjadi seseorang yang berjalan di atas air, menyembuhkan orang lain, yang sangat berbeda dengan pengalaman dirinya sendiri dalam dunia yang nyata. Dengan kata lain, ketika bertindak sebagai karakter atau avatar, pemain bisa menjadi orang lain, tidak ada yang bisa melihat seperti apa dia sebenarnya, prestasi apa nyata apa yang dia miliki, atau siapa dirinya sebenarnya. Hal ini yang mempengaruhi keinginan individu untuk menghabiskan lebih banyak dorongan dalam kepribadian alternatif mereka. Leisure, dalam menggunakan waktu luang untuk bermain bagi masyarakat Ledokombo, bagi gamer masyarakat kampung Tanoker Ledokombo, bermain video game sama dengan menonton. Bagi mereka satu unit perangkat komputer permainan video game dimainkan bersama-sama enam orang anak adalah hal yang biasa. Anak-anak rela duduk menonton berjam-jam menjadi penonton saja. Biasanya mereka yang tidak memiliki dana untuk membayar sewa video game cukup sebagai penonton saja.

\section{DAFTAR PUSTAKA}

Abu -Lughod, Lila.1993. Finding a Place for Islam : Egyptian Television Serials and the National Interest, London: Routledge

Ahlstrom, M.,Lundberg, N. R., 2012. Me, My Spouse, And My Avatar: The 
Relationship between Marital Satisfaction and Playing Massively Multiplayer Online Role-Playing Games (MMORPGs), Journal of Leisure Research, 44(1), 1+ Retrieved from http://go.galegroup.com/psi/i.do?

Alverson, B. 2016. Game Changers:Books Based on Video Games and Their Characters Have Broad Appeal, School Library Journal, 6(11), 30+Retrieved from http://go.galegroup.com/psi/i.do , 2004. Dramas of Nationhood

:The Politics of Television in Egypt, Chicago, IL : University of Chicago Press.

Baudrillard, Jean, 2015. Masyarakat Konsumsi, Bantul : Kreasi Wacana

Chen, K., Chen, \& Ross, 2010. Antecedents of Online Game Dependency: The Implications of Multimedia Realism and Uses and Gratifications Theory. Journal of Database Management, 21(2), 69+ Retrieved from http://go.galegroup.com/psi/i.do

Choi, Y.K.,Lee, S,M.,\& Li,H. 2013. Audio and Visual Distraction and Implicit Brand Memory: Astudy of Video Game Players, Journal of Advertising, 42(2-3) Retrieved from http://go.galegroup.com/psi/i.do?

Giddens, Anthony, 1999. Runaway World How Globalisation is Reshaping Our Lives, London: Profile Books Ltd

Huizinga, J. 1938. Homo Ludens, London, Boston and Henley. Kegan Paul Ltd.

Ida, Rachma, 2014. Metode Penelitian Kajian Budaya dan Studi Media, Jakarta: Kencana Prenada Media Group.

Kando, Thomas M, 1975. Leisure and Popular culture in Transition, London, Library of Congress Cataloging in Publication Data
Kuswarno, Engkus, 2008. Etnografi Komunikasi, Suatu Pengantar dan Contoh Penelitiannya, Bandung: Widya Padjajaran.

Matteson, A.2017. Build Games with Bloxels: with Cheery Blocks, Kids can Design Their Own Video Games, Coding not Required. School Library Journal, 63(5)+Retrieved from

http://go.galegroup.com/psi/i,di?

Piliang, Yasraf, Amir, 2004. Dunia Yang Berlari, Mencari Tuhan- Tuhan Digital, Jakarta: Grasindo. 2004. Posrealitas, Realitas Kebudayaan dalam Era Posmetafisika, Yogyakarta: Jalasutra.

Shi, W., Corrieveau, \& Agar J. 2014. Dead Reckoning Using Play Pattens in A Simple 2D, International Journal of Computer Games Technology. Retrieved from http://go.galegroup.com/psi/i.do?

Suryajaya, Martin, 2014. MarxismedanVideoGame, http://indoprogress. com/2014/04/ marxisme-dan- video-game/

Thomas, K.D.,\& Levant, R.F, 2012. Does The Endorsement of Tradisional Masculinity Ideology Moderate The Relationship Between Exposure To Violent Video Games and Aggression? The Jounal of Men's Studies, Retrieved from http://go.galegroup.com/psi/i.do?

Triono Akhmad Munib, Gangsar Parikesit, dan Boby Ibipurwo, 2011.Permainan Modern vs Permainan Tradisional (Makalah), Yogyakarta :UGM.

Veblen, $\quad 1994$.

TheTheoryofLeisureClass, Neww York: Penguin Books 
Velayati, Sisillia, 2014. Komunitas Tanoker Ledokombo: Pendorong Perubahan Sosial Pedesaan Melalui Pendekatan Budaya di Kecamatan Ledokombo, Kabupaten Jember, Jawa Timur, Malang : Universitas Brawijaya

Zackariasson,wilson, 2012. The Video Game Studi : Formation, Present State, and Future. London \& New York : Routledge http://.surabaya. tribunnews.com/ wujudkan ledokombo kawasan ramah anak (Diakses: 25 Februari 2015, 16:20)

http://news.liputan6.com/read/730876/vid eo-dengan-egrang-tanoker-ajarianak-anak-nilai-nilai-kehidupan (Diakses: 26 Maret 2015, 04:18) http://totalupdate.blogspot.com.Learn-tobuild-indonesia-from-tanoker.html (Diakses: 26 Maret 2015, 04:30) 